\title{
THE ROLE OF PARENTAL ATTENTION AND LEARNING MOTIVATION IN INCREASING STUDENTS' ENGLISH LEARNING ACHIEVEMENT
}

\author{
Viviana Lisma Lestari \\ UIN Syarif Hidayatullah Jakarta \\ viviana.lisma@uinjkt.ac.id
}

\begin{abstract}
The purpose of this study was to determine the effect of parents' attention on learning achievement in English, the effect of learning motivation on learning achievement in English and to determine the effect of parents' attention and motivation to learn on learning achievement in English simultaneously. The research method used was a survey. The sample size was 52 students; with the sampling technique used was random sampling. Hypothesis testing uses 2-way ANOVA test. The results showed that there was a significant influence of parents' attention and motivation to learn together on students' English learning achievement at MTSN 6 East Jakarta, as evidenced by the value of Sig = $0,000<0.05$ and $F$ count $=26.255$. There was a significant influence of parents' attention on students' English learning achievement at MTsN 6 East Jakarta, as evidenced by the value of Sig $=0.001<0.05$ and $t$ arithmetic $=3.380$. There was a significant influence of learning motivation on students' English learning achievement in MTsN 6 East Jakarta, as evidenced by the value of Sig $=0.004<0.05$. Parental attention and learning motivation had a significant effect on learning achievement.
\end{abstract}

Keywords: Parental attention, Motivation, Learning Achievement.

\section{INTRODUCTION}

Education is an effort to develop cognitive, affective and psychomotoric skills that are useful for students' lives both now and for the future. Education is also one of the most important elements in life.

Education is a dynamic force in the lives of any individual who influences their physical, mental, social and moral development, or in other words education is a dynamic force in influencing the ability, personality and individual life in his meetings and relationships with others, and his relationship with God.

The problems that commonly arise in the educational world, especially in school learning activities, are low student learning achievements. Learning achievement is a level of student's success in mastering lesson material that is realized by value or number. Students' success rate in education will be assessed through study results tests. 
The motivation to learn is one of the internal factors that affect learning achievement. According to Sardiman 2011:75), learning motivation can be said as the overall driving force of students who trigger learning activities, which guarantees the continuity of the learning activities and that gives direction to the learning activities, so that the objectives desired by the learning subjects can be achieved.

With the motivation of high learning, students will be able to do learning activities and always pay attention to the lesson so that learning achievements will be easy to achieve. In addition to learning motivation, Slameto (2010:60) argues that parents are the ones closest to the students. In the family environment, the parents' attention in children's learning is very influential in the child's learning performance. Thus, it can be concluded that the attention of parents is one of the other important factors that determines the learning achievement of students.

Parents' attention can be interpreted as a form of parental attitude that monitors every child's development. Parents should be aware that it has a huge role in the learning process of students. Ahmadi and Supriyono (2013:86) argue that, the affection of parents, attention or appreciation to children raises healthy mental for children. The attention of parents has a good impact on the children, such as improving the spirit and motivation of learning for them. The attention and guidance of parents at home will affect students' learning readiness, both at home and in school.

\section{Learning Achievement}

According to Jihad and Haris (2009: L4), the learning achievement is an achievement of the form of behavioral change that tends to settle from the cognitive, affective, and psychomotoric realm of the learning process done within a certain time.

English learning achievement can be defined as the knowledge and skills developed by the English language and expressed in the form of numbers given by the teacher as a result of the learning activities that have been achieved by students in a certain period. Student English learning achievement means the result that students have achieved in English language subjects.

Djamarah (2006:106) reveals that to measure and evaluate the success rate of learning, it can be done through a learning achievement test. Similarly, the English language achievement, that in order to measure the achievement of the study, can be done through the learning English achievement test.

According to Arikunto (2009:33-39), the terms of usability to measure students' learning performance is differentiated into three kinds of tests, namely diagnostic tests, formative tests and summative tests:

1. A diagnostic test is a test that is used to determine the weakness of the students so 
that based on these weaknesses it can be applied an appropriate treatment.

2. A formative test is a test that is intended to know the students' mastery over the program materials thoroughly as well as the extent to which the students have formed after following a particular program at school.

3. A summative test or summative evaluation is an evaluation of the expiration of a group of programs. This summative test can be a general test usually conducted at the end of the term.

In principle, the disclosure of achievement of learning is ideal when it encompasses all psychological realms that changed as a result of learning experience and process of students. However, the disclosure of behavior changes throughout the realm, particularly the psychological realm of students, is very difficult. This is due to the change in learning outcomes that are unpredictable.

Therefore, what the teacher can do in this case is to take a snapshot of the behavioral change that is considered important as a result of students' learning, both the dimension of cognitive, affective and dimension of psychomotor. In this regard, Muhibbin (2008:150-151) stated that measurement of study achievement can be done in 3 aspects/realm, such as (cognitive), realm of sense (affective), and karsa domain.

Based on the description, it can be concluded that the measurement of learning achievement can be done through several tests, while the learning achievement indicator (in this case the measured aspect) covers the realm of cognitive, affective, and psychomotor.

In this study the measurement of English language achievement was conducted through formative tests (in this case the competency test or the daily replay for such competence). Thus, measurements are carried out on the cognitive aspects of students.

Mudzakir (1997) expressed factors that affect the learning performance in general divided into two, external and internal factors. External factors are a factor that comes from outside of oneself, the factors include:

\section{Parental attention}

In a family environment, every individual or student needs parents' attention to achieve their learning achievements. Because this parents' attention will determine a student can achieve high learning achievement. Parents' attention is manifested in compassion, giving advice and so on.

\section{The parents' economic situation}

The family's economic situation also affects student learning achievements, sometimes students feel less confident in their family's economic circumstances. But there are also students, whose economic state is good, but the learning achievement is low or otherwise the students whose economic condition is low could gain high learning achievement. 


\section{Relationships between family members}

There must be a harmonious relationship between existing personnel in the family.

With the harmonious relationship between family members, it will have peace, serenity and tranquility. This can create a good learning condition, so that students' learning achievements can be achieved well too.

\section{Learning Motivation}

According to Winkel (1984:27), the motivation for learning is the overall driving force of the students that raises learning activities, which guarantees the continuity of the learning activities and that gives direction to the learning activities. From the explanation above it can be concluded that the motivation to learn is a driving force or a towing that encourage a person's behavior in order to have the willingness to act in learning.

The learning process will succeed if the students have high motivation in learning. Growing the motivation of learning is one of the duties and responsibilities of an educator. According to Sardiman (2012:85), motivation can serve as a business driver and achievement. So it can be concluded that if a student has motivation in learning, the student's learning achievement will increase.

According to Sardiman (2012-83), the motivation that exists in each person has its features: diligently facing tasks, resilient facing difficulties, requiring no outside encouragement to achievers should be possible, showing an interest in the various problems for adults, preferring to work independently, quickly getting bored on routine tasks, being able to defend his opinion, not easily releasing the thing that is believed to be, and enjoying finding and solving problems.

The conclusion that can be taken is if students have motivational traits such as diligently facing assignments then the student will always get a good value in each given task.

The motivation for learning is unlikely to grow on its own, many factors influencing the formation of learning motivation. According to Mudjiman (2007:43) There are eight factors that affect the formation of motivation learning such as factors of knowledge on the usability of learning, the learning need factor, the ability factor to conduct learning activities, the pleasure factor in the idea of conducting learning activities, the implementation factor of learning activities, learning outcomes Factors, satisfaction factor on learning outcomes, and factors of personal and environmental characteristics on the decision making process.

Learning motivation in English language can be interpreted as a physiological and psychological condition in the students who encouraged him to conduct learning activities in English subjects to gain achievement in the subjects as high as possible based on skills in English-related science. 


\section{Parents' attention}

According to Suryabrata (2008:14), attention is a lot of the least consciousness that accompanies the activity. Walgito (2010:101) expressed caution is the centering or concentration of all activities shown in a group or object. Attention according to Soemanto (2006:34) is the concentration of energy/soul strength on something. Caution is the utilization of consciousness to accompany an activity. This understanding can be interpreted that the attention of parents is the deployment or concentration of energy/life force of them to the learning activities of their children with full consciousness to achieve maximum achievement of the child in learning.

Parents' attention to child education is necessary and plays a role in determining the achievement of learning or the child's own success. Slameto (2010:61) reveals that some parents do not even pay attention to their children's education, for example they are indifferent to their children's learning activities, do not pay attention to the interests and needs of his children in learning, do not regulate the time of study, do not pay attention to the time of learning, do not provide or complement the learning tools, do not pay attention to children learn or not, do not want to know the progress of their children's learning or maybe the difficulties experienced in learning and others, can cause the children fail on their learning.

Based on the theory above, parents' attention to the children related to learning can be demonstrated by various forms of action. In this study there were five forms of attention that became indicators of the parents' attention on their children' learning, such as:

\section{Giving Reward (award)}

The reward is given in the form of praises or prizes. Prizes are given to children as a reward for it can be used to motivate children. Prizes are something that is given to other people as a tribute or misadventure. Gifts given by others can be anything, depending on the intention of the giver. Prizes can also be adjusted to the achievements achieved by a person.

\section{Giving punishment (penalty)}

Punishment is a negative reinforcement but is necessary in education. Penalties intended here are not like imprisonment or punitive punishment but is an educational act. This act is necessary in education.

Child mistakes because of violating discipline can be sanctioned penalties. The sanctions include sweeping the floor, noting missing subjects, or anything that is educational.

Providing guidance and assisting the difficulties According to Stoops in Hamalik (2012:193) guidance is a continual process to assist the development of individuals to enhance their ability to the fullest extent in obtaining maximum benefit. According to Dalyono (2009:240), children need guidance 
from their parents so that adult attitudes and learning responsibilities grow in children. Parents' business in working and in organizations or other things can result in children not getting guidance from their parents. As a result, it is likely that children will have troubles in learning and difficulties in achieving good learning achievements.

Parents who give guidance to their children in learning, will know the development of his son and also the difficulties and problems faced by his son. In this regard, Slameto (2010:64) suggests that parents are obliged to give understanding and encouraging them, helping to be as difficult as a child can suffer.

Parents need to contact their child's teacher to find out their progress. Thus, giving guidance and helping the difficulties faced by the child is a form of attention that can help and influence the child in the achievement of his learning achievement.

\section{Giving examples}

According to Ahmadi and supriyono (2013:87), parents are the closest example of his children. Everything that is made by parents unknowingly will be imitated by their children. Parents should always give examples by embedding good habits that can smoothen and support their children in learning.

In connection with this, Djamarah (2008:242) states that habits in a family that does not support, where the study habits exemplified and will be in the heart or near the new replay time learning all the way, then that habit is the example of children, although in fact it is a habit of wrong learning.

Based on the theory above, parents who are concerned about their children are parents who care about their child's learning habits. Therefore, parents who can give examples and instill positive habits that support children's learning will help the child obtain good achievement in their learning.

\section{Fulfilling children's learning needs}

Children's learning needs in this case are all the tools and means that children need to support their learning activities. Such learning needs can be stationery, textbooks and textbooks, study room, table, chairs, lighting, and others.

Walgito (2010:146) states that learning will not go well without sufficient learning tools. The learning process will be interrupted if the necessary tools do not exist. The more complete the tools, the easier it will be to learn the most. Conversely, if the appliance is incomplete then the learning process will be interrupted.

\section{Problem Statement}

Based on the background of the problem, identification and limitation of the problem above, the problem formulation is as follows:

1. Is there an influence of parents 'attention and motivation to learn together on MTsN 6 students' English learning achievement in East Jakarta. 
2. Is there an influence of parents 'attention on MTsN 6 students' English learning achievement in East Jakarta.

3. Is there an influence of learning motivation on MTsN 6 students' English learning achievement in East Jakarta.

\section{Scope the Research}

Considering the breadth of the scope of this study, this study is limited to the issue of the effects of parents and learning motivation on learning achievement in English (Survey on MTsN 6 in East Jakarta).

\section{METHODS}

This type of research used in this research is explanatory research or explanatory research with quantitative approaches. The number of samples was 52 respondents in The state Islamic Junior High School 6 Jakarta. The sampling technique used random sampling technique that is the sample is taken randomly.

\section{Data analysis techniques used are:}

\section{a. Descriptive analysis}

Descriptive analysis is needed on research variables. Based on these variables, analysis can be done to get information about many things. (Umar, 2011)

\section{b. multiple linear regression analysis}

Analysis of multiple linear equation models is used to simultaneously regress between independent variables and dependent variables.
In this study the regression model used is:

$$
Y=a+b_{1} X_{1}+b_{2} X_{2}+e
$$

Information:

$\mathrm{Y} \quad$ = Dependent variable (customer loyalty)

$\mathrm{X}_{1}=$ free variable (service quality)

$\mathrm{X}_{2}=$ Independent variable (Satisfaction)

$\mathrm{a}=$ constant

$b_{1}, b_{2}=$ regression coefficient

\section{c. F test}

To test the effect of the independent variables simultaneously on the dependent variable.

\section{d. T test}

$T$ test was conducted to test the significance of each independent variable partially

\section{FINDINGS AND DISCUSSION}

\section{Finding}

The influence of parents' attention (X1) and the motivation to learn (X2) together towards English learning achievement $(\mathrm{Y})$

The hypothesis tested:

$H_{0}: \beta_{y 1}=\beta_{y 2}=0$

$H_{1}: \beta_{y 1} \neq 0$

\section{Means:}

$\mathrm{HO}$ : There is no influence on parents' attention and the motivation to learn in conjunction with English learning achievements

$H 1$ : There is the influence of parents' attention and the motivation to learn together with the achievement of English learning 
Tabel 1. Calculation result of variable multivariate regression equation $\mathrm{X} 1$ and $\mathrm{X} 2$ against $Y$

Coefficients $^{2}$

\begin{tabular}{|c|c|c|c|c|c|c|}
\hline \multirow{3}{*}{\multicolumn{2}{|c|}{ Model }} & Coef & ac lents" & & & \\
\hline & & \multicolumn{2}{|c|}{$\begin{array}{l}\text { Unstandardized } \\
\text { Coefficients }\end{array}$} & \multirow{2}{*}{$\begin{array}{c}\text { Standardize } \\
d \\
\text { Coefficient } \\
s \\
\text { Beta }\end{array}$} & \multirow[t]{2}{*}{$\mathrm{t}$} & \multirow[t]{2}{*}{ Sig. } \\
\hline & & B & Std. Error & & & \\
\hline \multirow{3}{*}{1} & (Constant) & 61.059 & 1.951 & & 31.299 & .000 \\
\hline & $\begin{array}{l}\text { PARENTS } \\
\text { ATTENTION }\end{array}$ & .150 & .044 & .421 & 3.380 & .001 \\
\hline & $\begin{array}{l}\text { MOTIVATION TO } \\
\text { LEARN }\end{array}$ & .116 & .038 & .382 & 3.064 & .004 \\
\hline
\end{tabular}

From the table above, it can be stated that there is a significant influence on parents' attention and the motivation to learn in tandem with learning English. This is evidenced by the acquisition of the value Fo $=26,255$ and Sig. $0.000<0.05$

\section{DISCUSSION}

Equations of double regression lines can be expressed with $Y=61.059+0.116 \mathrm{X} 1+$ $0.150 \times 2$. This has the notion that a one-score variable increase in parental attention and motivation to learn to contribute amounted to 0.116 by $\mathrm{X} 1$ and 0.150 by $\mathrm{X} 2$ against a variable of English-learning achievement. From the table 4.9, it can also explain that collectively the attention of parents and motivation to learn contribute $51.7 \%$ of the variable of English language achievement.

Influence of parents' attention (X1) to English Learning achievement $(\mathrm{Y})$

The hypothesis tested:

$$
\begin{aligned}
& \mathrm{H}_{0}: \beta_{\mathrm{y} 1}=0 \\
& H_{1}: \beta_{y 1} \neq 0
\end{aligned}
$$

Means:

$\mathrm{HO}$ : There is no influence on parents' attention to English learning achievements

H1: An influence of parents' attention to English learning achievement

From table 1, it can be noted that there is a significant influence on parents' attention to English language achievement. This is evidenced by the acquisition of the value of Sig. $0.001<0.05$.

The variable contributions of parents' attention to English learning achievements can be expressed by the formula:

$C D=\beta_{-} \times 1 y \times$ value of its stake correlation (r_x1y) $\times 100 \%$

$C D=0.652 \times 0.421 \times 100 \%=27.5 \%$

From the results of the above calculations it can be stated that the contribution of parents' attention in improving English learning performance amounted to $27.5 \%$

The influence of motivational learning (X2) on English Learning achievement $(Y)$

The hypothesis tested:

H_0: $\beta \_y 1=0$

H_1: $\beta \_y 1 \neq 0$

Means:

$\mathrm{HO}$ : There is no motivation to learn to learn to learn English language achievement

$\mathrm{H} 1$ : There is a motivation to learn about English language achievement 
From table 1, It can be stated that there is a significant influence of motivation to learn about English language achievement. This is evidenced by the acquisition of the value of Sig. $0.004<0.05$.

As for contributing variables motivation to learn to English learning achievements can be expressed with the formula:

$C D=\beta_{-} x 2 y \times$ value of its stake correlation $\left(r \_x 2 y\right) \times 100 \%$

$C D=0.636 \times 0.382 \times 100 \%=24.3 \%$

From the results of the above calculations can be stated that the contribution of parents' attention in improving English learning performance amounted to $24.3 \%$.

\section{CONCLUSION AND SUGGESTION}

\section{Conclusion}

In this part of the conclusion, the author briefly described the results of the research obtained in the field. After the research and data analysis of the influence of parents' attention and the motivation to learn on the achievement of English language, it can be drawn conclusions as follow:

1. There is a significant influence of parents' attention and the motivation to learn together to study English students at MTsN 6 East Jakarta. It is evidenced by the value of Sig $=0.000<0.05$ and $\mathrm{F}$ count $=26.255$.

2. There is a significant influence of parents' attention to student English learning achievement at MTsN 6 East Jakarta. It is evidenced by the value of Sig $=0.001<$ 0.05 and $t$ count $=3.380$

3. There is a significant influence of motivation to learn to language learning Achievement 3. English students at MTsN 6 East Jakarta. This is evidenced by the value of Sig $=0.004<0.05$ and $\mathrm{t}$ count $=3.064$.

\section{Suggestion}

1. Parents continue to increase their attention so as to give a positive influence on students' English learning achievements.

2. The school strives for the quality of teaching and learning process by optimizing related elements, both human resources and infrastructure to increase the students' learning motivation so that there are positive effects on students' English learning achievement in school.

3. Students always appreciate their parents' attention and improve their learning motivation as this provides an excellent impact on their English learning and achievement.

\section{REFERENCES}

A.M, Sardiman. (2012). Ineraksi dan Motivasi Belajar Mengajar. Jakarta: Rajawali Pers.

Ahmadi, A. Supriyono, W. (2013). Psikologi Belajar. Jakarta : PT. Rineka Cipta.

Dalyono, M. (2009). Psikologi Pendidikan. Jakarta : Rineka Cipta. 
Djamarah, S.B (2006). Guru dan Anak Didik dalam Interaksi Edukatif. Jakarta: Rineka Cipta.

Djamarah, S.B. (2008). Psikologi Belajar. Jakarta: Rineka Cipta.

Hamalik, O. (2012). Manajemen Pengembangan Kurikulum.. Bandung: Remaja Rosdakarya

Jihad,A. Haris, A. (2009). Evaluasi Pembelajaran. Yogyakarta: Multi. Press.

Mudjiman, H. (2007). Belajar Mandiri (Self Motivated Learning). Surakarta: LPP UNS dan UNS Press.

Mudzakir, Ahmad. Joko Sutrisno. 1997. Psikologi Pendidikan. Pustaka Setia. Bandung

Slameto. (2010). Belajar dan Faktor-faktor yang Mempengaruhinya. Jakarta: PT Rineka Cipta.
Soemanto, W. (2006). Psikologi Pendidikan: Landasan Kerja Pemimpin. Jakarta: Rineka Cipta.

Suryabrata, S. (2008). Metodologi Penelitian. Jakarta : PT. Raja Grafindo Persada.

Syah, M. (2008). Psikologi Belajar. Bandung: PT. Remaja Rosdakarya.

Umar, Husein. 2011. Metode Penelitian Untuk Skripsi dan Tesis Bisnis, Edisi kedua. Jakarta: Raja Grafindo Persada.

Walgito, B. (2010). Pengantar Psikologi Umum. Yogyakarta: C.V Andi.

Winkel, W.S.(1984). Psikologi Pendidikan dan Evaluasi Belajar. Jakarta: Gramedia. 